\title{
PENGARUH LINGKUNGAN DAN KEMAMPUAN KERJA TERHADAP KINERJA KARYAWAN PT. RONADAMAR SEJAHTERA CABANG BANDUNG
}

\author{
Riza Widyanata \\ Universitas Pendidikan Indonesia \\ rizawidyanata@gmail.com \\ Dr. H Syamsul Hadi Senen \\ Universitas Pendidikan Indonesia \\ sh_senen@yahoo.com
}

\begin{abstract}
ABSTRAK
Latar belakang penelitian ini adalah rendahnya kinerja karyawan. Hal tersebut diindikasikan dengan menurunnya kinerja karyawan, dan menurunnya jumlah penjualan. Fenomena tersebut harus segera ditangani karena karyawan memiliki peranan penting dalam mencapai sebuah tujuan perusahaan. Lingkungan kerja dan kemampuan kerja dijadikan sebagai cara untuk meningkatkan kinerja karyawan.

Tujuan penelitian ini adalah untuk mengetahui gambaran Lingkungan kerja, Kemampuan kerja, Kinerja karyawan, Besarnya pengaruh lingkungan kerja terhadap kinerja karyawan, Besarnya pengaruh Kemampuan kerja terhadap kinerja karyawan, Besarnya pengaruh Lingkungan kerja dan kemampuan kerja terhadap kinerja karyawan.

Objek dalam penelitian ini adalah karyawan PT. Ronadamar Sejahtera di Bandung. Variabel bebas (X) dalam penelitian ini adalah lingkungan kerja dan kemampuan kerja, serta veriabel terikat (Y) yaitu kinerja karyawan. Jenis penelitian yang digunakan adalah deskriptif dan verifikatif. Metode yang digunakan dalam penelitian ini adalah metode explanatory survey dengan teknik sampel jenuh dengan jumlah sampel sebanyak 37 orang. Teknis analisis data yang digunakan dalam penelitian ini adalah regresi linear berganda, dengan bantuan program SPSS 21.0 for windows.

Hasil temuan dalam penelitian ini antara lain sebagai berikut: lingkungan kerja pada PT. Ronadamar Sejahtera dalam kategori baik, kemampuan kerja pada PT. Ronadamar Sejahtera juga dalam kategori baik, kinerja karyawan PT. Ronadamar Sejahtera dalam kategori tinggi, kinerja karyawan dipengaruhi secara positif oleh lingkungan kerja dengan korelasinya sebesar 7,8\%, kinerja karyawan dipengaruhi secara positif oleh kemampuan kerja dengan korelasinya sebesar $66,5 \%$, kinerja dipengaruhi secara positif oleh lingkungan kerja dan kemampuan kerja dengan koefesien determinasinya sebesar 49,8\%.
\end{abstract}

Kata Kunci: Lingkungan Kerja, Kemampuan Kerja, Kinerja Karyawan

\section{PENDAHULUAN}

Setiap perusahaan mempunyai tujuan yang harus dicapai. Tujuan tersebut dapat tercapai dengan bantuan sumber daya manusia yang baik. Sumber daya manusia yang baik akan membantu perusahaan dalam pencapaian tujuan yang telah direncanakan, maka perusahaan perlu memberikan pengarahan kepada karyawannya. Selain itu perusahaan perlu memperhatikan lingkungan kerja di tempat kerja seperti fasilitasfasilitas yang akan membantu karyawan dalam penyelesaian tugasnya. Kemampuan kerja karyawan juga perlu diperhatikan karena jika karyawan bekerja sesuai dengan kemampuannya maka karyawan akan menyenangi dan lebih cepat menyelesaikan pekerjaannya. Seperti pada perusahaan yang bergerak di bidang industri perekat yang sedang berkembang, lingkungan dan kemampuan kerja perlu diperhatikan demi kemajuan perusahaan.

Perkembangan industri perekat mengalami pekembangan yang cukup pesat. Perkembangan ini dapat dilihat dari meningkatnya perusahaan yang memproduksi perekat di Indonesia. Dengan peningkatan ini, berarti meningkat pula persaingan dalam industri perekat di Indonesia. Menurut data Kementerian Perindustrian terdapat kurang lebih 47 perusahaan di Indonesia yang bergerak dalam bidang perekat. Akan tetapi persaingan yang cukup pesat diantara perusahaan perekat harus diimbangi dengan kinerja yang baik. Setiap perusahaan dituntut untuk memiliki sumber daya manusia yang berkualitas yaitu mempunyai kinerja karyawan yang baik, karena dengan kinerja yang baik akan membantu tercapainya tujuan sebuah perusahaan. Sedangkan kinerja yang rendah akan menghambat proses tercapainya tujuan perusahaan, maka dari itu setiap perusahaan harus mengantisipasi agar tidak terjadi rendahnya kinerja karyawan. Akan tetapi rendahnya kinerja pasti dapat dialami oleh setiap perusahaan, tak terkecuali perusahaan perekat 
PT. Ronadamar Sejahtera Bandung yang mengalami permasalahan tersebut.

PT. Ronadamar Sejahtera Bandung merupakan perusahaan distributor lem dari PT. Aica Indria. PT. Aica Indria merupakan perusahaan yang membuat lem yang digunakan untuk kayu pembangunan, furniture, kertas, dan juga untuk pengemasan (packaging) suatu produk. PT. Ronadamar Sejahtera Bandung akan menyuplai barangnya ke daerah-daerah Jawa Barat kecuali Kota Bogor dan Cirebon.

Kualitas sumber daya manusia di perusahaan ini sangatlah penting, karena untuk mencapai tujuan-tujuan dari perusahaan seperti meningkatkan penjualan dan memperluas wilayah dapat dilakukan oleh karyawan di

\section{TABEL 1}

REKAPITULASI PENILAIAN KINERJA KARYAWAN PT. RONADAMAR SEJAHTERA TAHUN 2010-2014

\begin{tabular}{|c|c|c|c|c|c|c|c|c|c|c|}
\hline \multirow[b]{3}{*}{$\begin{array}{c}\text { Nilai } \\
\text { Kinerja }\end{array}$} & \multicolumn{10}{|c|}{ Periode } \\
\hline & \multicolumn{2}{|c|}{2010} & \multicolumn{2}{|c|}{2011} & \multirow{2}{*}{$\begin{array}{c}2012 \\
\begin{array}{c}\text { Jumlah } \\
\text { karyawan }\end{array}\end{array}$} & \multirow[b]{2}{*}{$\%$} & \multirow{2}{*}{$\begin{array}{c}2013 \\
\begin{array}{c}\text { Jumlah } \\
\text { karyawan }\end{array}\end{array}$} & \multirow[b]{2}{*}{$\%$} & \multirow{2}{*}{$\begin{array}{c}2014 \\
\begin{array}{c}\text { Jumlah } \\
\text { karyawan }\end{array}\end{array}$} & \multirow[b]{2}{*}{$\%$} \\
\hline & $\begin{array}{c}\text { Jumlah } \\
\text { karyawan }\end{array}$ & $\%$ & $\begin{array}{c}\text { Jumlah } \\
\text { karyawan }\end{array}$ & $\%$ & & & & & & \\
\hline $\begin{array}{l}\text { Baik } \\
\text { Sekali }\end{array}$ & 11 & 28,2 & 14 & 36,8 & 1 & 2,7 & 6 & 16,2 & 6 & 16,2 \\
\hline Baik & 19 & 48,7 & 7 & 18,4 & 25 & 67,5 & 7 & 18,9 & 9 & 24,3 \\
\hline Cukup & 5 & 12,8 & 2 & 5,2 & 8 & 21,6 & 17 & 45,9 & 6 & 16,3 \\
\hline Kurang & 2 & 32,8 & 14 & 36,8 & 3 & 8,1 & 7 & 18,9 & 16 & 43,2 \\
\hline Buruk & - & - & - & - & - & - & - & - & - & - \\
\hline $\begin{array}{l}\text { Buruk } \\
\text { Sekali }\end{array}$ & - & - & - & - & - & - & - & - & - & - \\
\hline Jumlah & 39 & 100 & 38 & 100 & 37 & 100 & 37 & 100 & 37 & 100 \\
\hline
\end{tabular}

Sumber : PT. Ronadamar Sejahtera Bandung (2015)

Berdasarkan hasil penilaian kinerja karyawan tersebut, dapat terlihat bahwa rata-rata kinerja karyawan mendapatkan nilai $\mathrm{B}$, namun ada beberapa departement yang mendominasi nilai C di 3 tahun terakhir dan D di tahun 2014 yang berarti penurunan kinerja terjadi sebesar $25 \%$. Hal ini menunjukkan bahwa kinerja karyawan belum optimal.

Perusahaan mengkategorikan nilai A adalah amat baik, B adalah baik, $\mathrm{C}$ adalah cukup dan nilai terendah D yaitu kurang, maka data di atas menunjukkan kinerja karyawan yang harus diatasi karena perusahaan mengharapkan nilai $\mathrm{A}$ di setiap departemennya.

Penilaian tersebut didasarkan atas mutu pekerjaan, kejujuran, inisiatif pengetahuan, tanggung jawab, dan pemanfaatan waktu yang dikerjakan oleh karyawan.

Berdasarkan hasil wawancara dengan Bapak Paulus Parera selaku General Manager PT. Ronadamar Sejahtera pada hari Rabu, 15 Januari 2014 pukul 10.30 WIB, bahwa rendahnya kinerja di perusahaan salah satunya diakibatkan oleh belum optimalnya tingkat kehadiran, yang akan berdampak pada pekerjaan yang terganggu. Adapun data rekapitulasi perusahaan tersebut. Hal tersebut harus dimiliki pula oleh PT. Ronadamar Sejahtera Bandung, sebagai perusahaan distributor PT. Ronadamar Sejahtera Bandung harus memiliki kinerja yang baik karena dituntut untuk menyuplai barang tepat waktu kepada konsumen yang membutuhkan.

Kinerja karyawan dapat diindikasikan belum baik pula dapat dilihat dari hasil penilaian kinerja karyawan perusahaan tersebut. Penilaian kinerja karyawan PT. Ronadamar Sejahtera Bandung dilakukan satu tahun sekali setiap bulan Desember. Adapun rekapitulasi penilaian kinerja karyawan PT. Ronadamar Sejahtera Bandung Tahun 2010-2014 berikut ini. 
Seharusnya setiap karyawan mengikuti aturan perusahaan yang menentukan bahwa diharuskan datang pada jam 07.30. Dengan banyaknya karyawan yang terlambat akan mengurangi tingkat efisiensi kerjanya, sehingga pekerjaan yang ditugaskan akan kurang maksimal dan tujuan perusahaan akan tertunda. Kehadiran karyawan yang menurun serta karyawan yang datang terlambat cukup tinggi akan mempengaruhi kinerja perusahaan. Pekerjaan yang seharusnya dikerjakan lebih awal akan terhambat dikarenakan karyawannya datang terlambat.

Sebagai perusahaan yang mendistribusikan lem ke daerah hampir seluruh Jawa Barat menginginkan karyawan yang memiliki pengalaman kerja serta pengetahuan karyawan akan sangat dibutuhkan karena produk yang bermacam-macam dan fungsi akan mengharuskan karyawan memiliki kemampuan yang lebih.

Tercapainya tujuan perusahaan hanya dimungkinkan karena upaya para pelaku yang terdapat pada perusahaan tersebut. Terdapat hubungan erat antara kinerja perorangan dengan kinerja perusahaan, bila kinerja karyawannya baik, maka kemungkinan besar kinerja perusahaannya juga baik. Tingkat kehadiran, kinerja bisnis, kinerja karyawan yang menurun akan mempengaruhi kinerja di perusahaan, maka perlu ada upaya dalam meningkatkan kinerja karyawan. Selain tingkat kehadiran, kinerja bisnis, kinerja karyawan yang mempengaruhi kinerja perusahaan.

Salah satu upaya dalam menghasilkan kinerja karyawan yang baik dan meningkatkan kinerja karyawannya dapat dilakukan dengan menciptakan lingkungan kerja yang nyaman, aman, kondusif, dan menyenangkan. Karyawan akan merasa nyaman ketika berada di lingkungan kerjanya dan akan mempengaruhi kinerjanya, seperti warna, kebersihan, sirkulasi udara, penerangan, music, keamanan, dan kebisingan dengan hal tersebut karyawan akan senang terhadap pekerjaannya dan dapat diselesaikan tepat waktu. Hal ini sesuai menurut Nitisemito (2006:39) yang mengemukakan bahwa "lingkungan kerja adalah segala sesuatu yang ada di sekitar para karyawan dan yang dapat mempengaruhi diri karyawan tersebut dalam menjalankan tugas-tugas yang dibebankan."

Selain lingkungan kerja yang dapat mempengaruhi kinerja karyawan kemampuan seorang karyawan pun dapat berpengaruh terhadap kinerja karyawan. Menurut Robbins (2003: 40) kemampuan atau ability menunjukkan kapasitas individu untuk mewujudkan berbagai tugas dalam pekerjaan. Hal ini membuktikan bahwa kemampuan seorang karyawan akan berpengaruh terhadap kinerja karyawan itu sendiri.

Berdasarkan hasil wawancara dengan Bapak Paulus Parera selaku General Manager PT. Ronadamar Sejahtera pada hari Rabu, 15 Januari 2014, bahwa dalam upaya untuk meningkatkan kinerja karyawan perlu memperbaiki lingkungan kerja yang diterapkan di perusahaan baik lingkungan yang berhubungan langsung dengan karyawan dan berada di dekat karyawan, dan lingkungan umum atau lingkungan kerja yang mempengaruhi kondisi manusia. Selain itu mengadakan seminar tahunan yang bertujuan untuk meningkatkan pengetahuan dan kemampuan karyawan yang dapat meningkatkan kinerja melalui kemampuan setiap karyawannya.

Berdasarkan penjelasan pada latar belakang tersebut, maka perlu dilakukan penelitian yang berjudul "Pengaruh Lingkungan Kerja dan Kemampuan Kerja terhadap Kinerja Karyawan PT. RONADAMAR SEJAHTERA BANDUNG."

Adapun tujuan yang akan dicapai dari penelitian ini adalah untuk mendapat hasil temuan mengenai: 1) Gambaran lingkungan kerja PT Ronadamar Sejahtera di Bandung, 2) Gambaran kemampuan kerja PT Ronadamar Sejahtera di Bandung, 3) Gambaran kinerja karyawan PT Ronadamar Sejahtera di Bandung, 4) Pengaruh lingkungan kerja dan kemampuan kerja terhadap kinerja karyawan PT Ronadamar Sejahtera di Bandung, 5) Pengaruh lingkungan kerja terhadap kinerja karyawan PT Ronadamar Sejahtera di Bandung, 6) Pengaruh kemampuan kerja terhadap kinerja karyawan PT Ronadamar Sejahtera di Bandung.

\section{KAJIAN PUSTAKA}

Pendekatan yang digunakan dalam penelitian ini adalah Manajemen Sumber Daya Manusia. Veithzal Rivai (2010:1) mengemukakan bahwa Manajemen Sumber Daya Manusia (MSDM) merupakan salah satu bidang dari manajemen umum yang meliputi segi-segi perencanaan, pengorganisasian, pelaksanaan dan pengendalian. Proses ini terdapat dalam fungsi atau bidang produksi, pemasaran, keuangan maupun kepegawaian. Karena sumber daya manusia dianggap penting perannya dalam mencapai tujuan perusahaan, maka berbagai pengalaman dan hasil penelitian dalam bidang SDM dikumpulkan secara sistematis dalam apa yang disebut manajemen sumber daya manusia. istilah "manajemen" mempunyai arti sebagai kumpulan pengetahuan tentang bagaimana seharusnya me-manage (mengelola) sumber daya manusia.

Manajemen sumber daya manusia (MSDM) adalah "kebijakan dan praktik menentukan aspek 
"manusia" atau sumber daya manusia dalam posisi manajemen, termasuk merekrut, menyaring, melatih, memberi penghargaan dan penilaian" (Sedarmayanti, 2014: 13). Sedangkan menurut Triyono (2012: 14-15), mendefinisikan bahwa manajemen sumber daya manusia adalah pengelolaan organisasional baik individual maupun kolektif terhadap asset manusia untuk memberikan kontribusi optimal dalam mencapai sasaran organisasi.

Adapun fungsi-fungsi manajemen SDM, menurut Veithzal Rivai dan Ella Jauvani Sagala (2010:13) yaitu Fungsi manajerial yang terdiri dari perencanaan (planning), pengorganisasian (organizing), pengarahan (directing), pengendalian (controlling). Fungsi operasional yang terdiri dari pengadaan tenaga kerja (SDM), pengembangan, kompensasi, pengintegrasian, pemeliharaan, pemutusan hubungan kerja.

Menurut Sunyoto (2012:5) fungsi pengarahan adalah mengusahakan agar karyawan mau bekerja secara efektif melalui perintah motivasi. Ada beberapa faktor yang dapat memotivasi karyawan agar memiliki kinerja yang baik, menurut A. Dale Timpe dalam Mangkunegara (2012:15) faktor yang mempengaruhi kinerja karyawan yaitu faktor internal dan faktor eksternal. Faktor internal yaitu faktor yang dihubungkan dengan sifat sifat seseorang. Faktor eksternal yaitu berasal dari lingkungan. Seperti perilaku, sikap, tindakantindakan rekan kerja, bawahan atau pimpinan, fasilitas kerja, dan iklim organisasi.

Berdasarkan pada pengelompokan fungsi operasional terdapat fungsi pengembangan, menurut Danang Sunyoto (2012:7) fungsi pengembangan berkaitan denngan peningkatan keterampilan dan kemampuan yang diupayakan melalui jalur pelatihan maupun pendidikan terhadap sumber daya manusia yang ada. Maka kemampuan kerja yang baik harus dimiliki oleh setiap karyawan untuk menjalani aktivitas atau tugas-tugas yang diberikan oleh suatu perusahaan.

Pekerjaan yang dilakukan oleh karyawan akan lebih mudah jika lingkungan kerjanya mendukung. Menurut Danang Sunyoto (2012:43) lingkungan kerja merupakan segala sesuatu yang ada di sekitar para pekerja dan yang dapat memengaruhi dirinya dalam menjalankan tugastugas yang dibebankan, misalnya kebersihan, musik, penerangan dan lain-lain.

Elton Mayo mengadakan penelitian pada perusahaan lampu pijar. Penelitian ini disebut hawthorne studies yang dilakukan dengan membagi karyawan ke dalam dua ruangan A dan B. Pada ruangan A diadakan perbaikan ventilasi, penerangan, dan pengarahan secara persuasif, sedang pada ruangan B tidak. Hasilnya ternyata produktivitas kerja karyawan di ruangan A meningkat walaupun kompensasi tidak dinaikkan, sedang di B tetap. Berdasarkan penelitian ini terbukti bahwa kebutuhan karyawan bukan hanya peningkatan kompensasi saja, tetapi mereka membutuhkan perlakuan yang baik, prasarana yang baik, dan lain sebagainya.

Selain lingkungan kerja, kemampuan kerja memiliki peranan penting dalam menyelesaikan pekerjaan. Kemampuan kerja merupakan bagian dari fungsi pengembangan dalam fungsi operasional Manajemen Sumber Daya Manusia. Sutermeister dalam Sedarmayanti (2009:83) mengemukakan bahwa "Work ability is deemed to result from knowledge and skill, ini berarti bahwa kemampuan seorang karyawan dihasilkan dari pengetahuan (knowledge) dan keterampilan (skill). Berikut penjabaran dimensi pengetahuan (knowledge) dan keterampilan (skill): Nevizond Chatab (2009:242) mengungkapkan bahwa ability (kemampuan) individu adalah kapasitas para individu untuk melaksanakan berbagai tugas dan aktivitas dalam suatu pekerjaan/jabatan. Kapasitas individu dipengaruhi oleh kontribusi pengetahuan (knowledge), keterampilan (skill) dan sikap (attitude) yang tertanam dialam pikirannya yang berasal dari diri sendiri, orang tua, guru, lingkungan dan lainnya.

Robbins dalam Badeni (2013:13) mendefinisikan bahwa "ability refers to an individual's capacity to perform the various task in job." Kemampuan mencakup arti yang luas yaitu keseluruhan potensi yang dimiliki seseorang untuk melakukan bervariasi dalam pekerjaan. Berbagai kemampuan yang dimiliki oleh manusia ini pada umumnya dapat diklasifikasikan menjadi kemampuan intelektual dan kemampuan fisik. Robbins dalam Badeni (2013:13) mengklasifikasikan menjadi technical skill, conceptual skill, and human skill, technical skill atau kemampuan teknis adalah kemampuan yang dimiliki seseorang yang berhubungan dengan pekerjaan-pekerjaan terkait hal-hal fisik seperti mengerjakan sebuah meja, kursi, memotong kayu, mengukir kayu menjadi sesuatu yang lebih bernilai. Conceptual skill atau kemampuan konseptual adalah kemampuan seseorang untuk melihat mutu permasalahan dengan berbagai faktor yang terkait di dalamnya. Sedangkan human skill atau kemampuan manusiawi yaitu kemampuan seseorang untuk bekerja sama dengan orang lain, memahami orang lain, dan mempengaruhi orang lain. Klasifikasi lain menyatakan dengan ability to do, ability to use concept, and ability to coordinate (Leslie W. Rue, Lloyd L. Byers dalam Badeni , 2013: 13).

Greenberg dan Baron dalam Wibowo (2013:93) mengungkapkan pengertian kemampuan sebagai kapasitas mental dan fisik untuk mewujudkan berbagai tugas. Orang 
berbeda dalam hubungannya dengan sejumlah kemampuan, namun dapat dikelompokkan dalam dua kategori, yaitu Intellectual Abilities and Physical Abilities. Hal ini serupa dengan yang diungkapkan Robbins, hanya ditekankan oleh mereka bahwa dalam intellectual abilities termasuk mewujudkan berbagai tugas kognitif.

Robbins dalam Badeni (2013:14) mengklasifikasikan kemampuan menjadi intellectual and physical abilities dengan berbagai dimensinya. Kemampuan intelektual adalah kemampuan yang diperlukan untuk melaksanakan aktivitas-aktivitas mental. Contoh tes IQ (intelligent quotient) digunakan untuk menegaskan seberapa tingkat kemampuankemampuan intelektual umum. Ada 7 (tujuh) dimensi kemampuan intelektual, yaitu number aptitude, verbal comprehension, perceptual speed, inductive reasoning, deductive reasoning, spatial visualization and memory. Kemampuan kognitif sangat relevan dengan pekerjaan dan menyangkut pekerjaan yang melibatkan penggunaan informasi untuk membuat keputusan dan pemecahan masalah. Sedarmayanti (2012:223) mengungkapkan bahwa kemampuan fisik merupakan kemampuan yang diperlukan untuk melakukan tugas menurut stamina, kecekatan, kekuatan, keterampilan serupa.

Lingkungan kerja dan kemampuan kerja akan mempengaruhi kinerja karyawan. Menurut Veithzal Rivai (2010: 548) Kinerja merupakan fungsi dari motivasi dan kemampuan. Kinerja merupakan perilaku nyata yang ditampilkan setiap orang sebagai prestasi kerja yang dihasilkan oleh karyawan sesuai dengan perannya dalam perusahaan. Kinerja karyawan merupakann suatu hal yang penting dalam upaya perusahaan untuk mencapai tujuannya. Arti kata performance merupakan kata benda (noun) di mana salah satu arti adalah "thing done" (sesuatu hasil yang telah dikerjakan). Sedarmayanti (2014:259) mengungkapkan bahwa kinerja terjemahan dari kata performance, yang berarti:

1. Perbuatan, pelaksanaan pekerjaan, prestasi kerja, pelaksanaan pekerjaan yang berdaya guna.

2. Pencapaian atau prestasi seseorang berkenan dengan tugas yang diberikan kepadanya.

3. Hasil kerja seorang pekerja, sebuah proses manajemen atau suatu organisasi secara keseluruhan, dimana hasil kerja tersebut harus dapat ditunjukkan buktinya secara konkrit dan dapat diukur.

4. Performance is defined as the record of outcomes produced on a specific job function or activity during a specific time period (Bernardian, John H.\&Joyce E. A. Russell, 1993:379). Kinerja didefinisikan sebagai catatan mengenai outcome yang dihasilkan dari suatu aktivitas tertentu, selama kurun waktu tertentu pula.

5. Hasil kerja yang dapat dicapai oleh seseorang atau kelompok orang dalam suatu organisasi, sesuai dengan wewenang dan tanggung jawab masing-masing, dalam rangka upaya mencapai tujuan organisasi bersangkutan secara legal, tidak melanggar hukum dan sesuai dengan moral maupun etika.

A.A. Anwar Prabu Mangkunegara (2012:9), mengungkapkan bahwa kinerja merupakan prestasi kerja atau hasil kerja (output) baik kualitas maupun kuantitas yang dicapai SDM persatuan periode waktu dalam melaksanakan tugas kerjanya sesuai dengan tanggung jawab yang diberikan kepadanya. Menurut Armstrong dan Baron dalam Wibowo (2012:7), menyebutkan bahwa kinerja merupakan hasil pekerjaan yang mempunyai hubungan kuat dengan tujuan strategis organisasi, kepuasan konsumen, dan memberikan kontribusi pada ekonomi.

Adapun aspek-aspek kinerja yang dinilai menurut Gomez-Mejia et al. (2012:225) yaitu: Quality of work (Kualitas pekerjaan), Quantity of work performed (Jumlah pekerjaan yang dilakukan), Interpersonal effectiveness (Efektivitas interpersonal), Competencies (Kompetensi).

Berdasarkan uraian tersebut dapat diketahui bahwa lingkungan kerja dan kemampuan kerja dapat mempengaruhi kinerja karyawan. Adapun paradigma dalam penelitian ini yaitu:

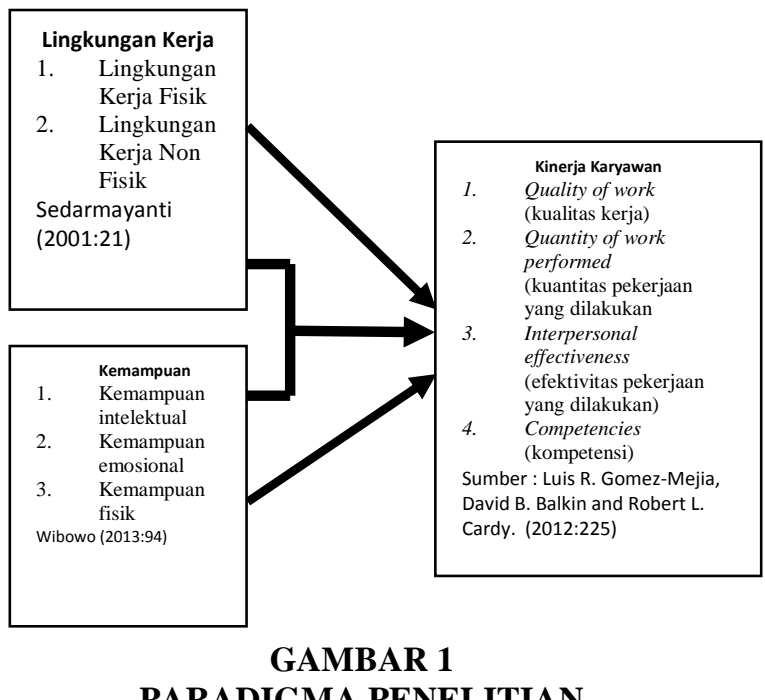

\section{METODELOGI PENELITIAN}

Objek penelitian ini adalah lingkungan kerja sebagai variabel bebas (independent variable) $\left(X_{1}\right)$, kemampuan kerja sebagai variabel bebas (independent variable) $\left(X_{2}\right)$ dan 
kinerja karyawan sebagai variabel terikat (dependent variable) (Y). Lingkungan kerja $\left(X_{1}\right)$ memiliki dimensi yaitu lingkungan kerja fisik, dan lingkungan kerja non fisik. Kemampuan $\left(X_{2}\right)$ memiliki dimensi yaitu kemampuan intelektual, dan kemampuan fisik. Penelitian ini dilakukan di salah satu cabang yang bergerak dalam pendistribusian perekat/lem, yaitu PT Ronadamar Sejahtera cabang Bandung yang berlokasi di Jalan Kopo Jaya 1 No. 7 Cirangrang Bandung.

Jenis penelitian ini adalah penelitian deskriptif dan verifikatif. Penelitian ini dapat mengetahui bagaimana pengaruh lingkungan dan kemampuan kerja terhadap kinerja karyawan PT Ronadamar Sejahtera Bandung. Penelitian deskriptif bertujuan untuk memperoleh gambaran mengenai pengaruh lingkungan dan kemampuan kerja terhadap kinerja karyawan PT Ronadamar Sejahtera Bandung. Berdasarkan jenis penelitian di atas maka dilakukan pengumpulan data di lapangan. Metode yang digunakan dalam penelitian ini adalah explanatory survey. Populasi dalam penelitian ini yakni karyawan PT Ronadamar Sejahtera yaitu sebanyak 37 orang. Pengambilan sampel dikarenakan populasi kurang dari 100 orang, maka sampel yang diambil adalah seluruh jumlah populasi karyawan.

Secara statistik, hipotesis yang akan diuji dalam rangka pengambilan keputusan penerimaan atau penolakan hipotesis dapat dirumuskan sebagai berikut:

1. Hipotesis 1

$H_{0}: \rho \leq 0$, Artinya tidak terdapat pengaruh dari lingkungan kerja dan kemampuan kerja terhadap kinerja karyawan

$H_{a}: \rho>0$, Artinya terdapat pengaruh positif dari lingkungan kerja dan kemampuan kerja terhadap kinerja karyawan

2. Hipotesis 2

$H_{0}: \rho \leq 0$, Artinya tidak terdapat pengaruh dari lingkungan kerja terhadap kinerja karyawan

$H_{a}: \rho>0$, Artinya terdapat pengaruh positif dari lingkungan kerja terhadap kinerja karyawan

3. Hipotesis 3

$H_{0}: \rho \leq 0$, Artinya tidak terdapat pengaruh dari kemampuan kerja terhadap kinerja karyawan

$H_{a}: \rho>0$, Artinya terdapat pengaruh positif dari kemampuan kerja terhadap kinerja karyawan

\section{HASIL PENELITIAN DAN PEMBAHASAN}

1. Pembahasan Deskriptif

A. Tanggapan Karyawan

\section{a. Lingkungan Kerja}

Berdasarkan hasil penelitian yang bersifat empirik mengenai pelaksanaan lingkungan kerja PT. Ronadamar Sejahtera, dihasilkan temuan bahwa lingkungan kerja fisik memberikan kontribusi yang cukup tinggi bagi karyawan dalam mencapai keberhasilan pelaksanaan lingkungan kerja

\section{b. Kemampuan Kerja}

Berdasarkan hasil penelitian yang bersifat empirik mengenai kemampuan kerja pada PT. Ronadamar Sejahtera, dihasilkan temuan bahwa kemampuan kerja di PT. Ronadamar Sejahtera baik, hal ini dilihat dari dimensi kemampuan kerja fisik yang telah memberikan kontribusi yang cukup tinggi bagi karyawan dalam mencapai kemampuan kerja.

\section{c. Kinerja Karyawan}

Berdasarkan hasil penelitian yang bersifat empirik mengenai kinerja karyawan pada PT. Ronadamar Sejahtera, dihasilkan temuan bahwa kinerja karyawan di PT. Ronadamar Sejahtera baik, hal ini dilihat dari dimensi kompetensi (competencies) yang telah memberikan kontribusi yang cukup tinggi dalam mencapai kinerja karyawan.

\section{Pembahasan Verifikatif}

Dengan menggunakan program SPSS 21.0 for Windows, diperoleh hasil koefisien regresi sebagai berikut:

TABEL 3

MODEL REGRESI LINEAR BERGANDA LINGKUNGAN KERJA DAN

KEMAMPUAN KERJA TERHADAP KINERJA KARYAWAN Coefficients $^{\mathrm{a}}$

\begin{tabular}{|c|c|c|c|c|c|}
\hline \multirow[t]{2}{*}{ Model } & \multicolumn{2}{|c|}{$\begin{array}{l}\text { Unstandardized } \\
\text { Coefficients }\end{array}$} & \multirow[t]{2}{*}{$\begin{array}{l}\text { Standardized } \\
\text { Coefficients }\end{array}$} & \multirow[t]{2}{*}{$\mathrm{t}$} & \multirow[t]{2}{*}{ Sig. } \\
\hline & B & $\begin{array}{l}\text { Std. } \\
\text { Error }\end{array}$ & & & \\
\hline (Constant) & 1.718 & 7.554 & & .227 & .821 \\
\hline $\begin{array}{ll} & \text { Lingkungan } \\
1 & \text { Kerja }\end{array}$ & .075 & .135 & .078 & .557 & .581 \\
\hline $\begin{array}{l}\text { Kemampuan } \\
\text { Kerja }\end{array}$ & 1.117 & .234 & .665 & 4.780 & .000 \\
\hline
\end{tabular}

a. Dependent Variable: Kinerja

Sumber: Hasil Pengolahan Data 2015

$$
\mathrm{Y}=1,718+0,75 \mathrm{X}_{1}+1,117 \mathrm{X}_{2}
$$

Berdasarkan persamaan regresi linear berganda di atas, konstanta sebesar 1,718 menyatakan bahwa jika tidak ada lingkungan kerja dan kemampuan kerja, maka besarnya kinerja karyawan sebesar 1,718. Koefisien regresi 0,75 satu satuan nilai artinya setiap terjadi peningkatan lingkungan kerja akan meningkatkan kinerja sebesar 0,75 satu satuan nilai dan sebaliknya jika terjadi penurunan kinerja, lingkungan kerja akan menurunkan kinerja sebesar 0,75 satu satuan nilai. Sedangkan koefisien regresi 1,117 satu satuan nilai artinya 
setiap terjadi peningkatan kemampuan kerja akan meningkatkan kinerja sebesar 1,117 satu satuan nilai dan sebaliknya jika terjadi penurunan kinerja, kemampuan kerja akan menurunkan kinerja 1,117 satu satuan nilai.

Hubungan antara lingkungan kerja dan kemampuan kerja terhadap kinerja karyawan diperoleh dari model summary yang dijelaskan secara rinci berikut:

TABEL 4

OUTPUT KOEFISIEN DETERMINASI Model Summary ${ }^{\mathrm{b}}$

\begin{tabular}{|c|r|r|r|r|r|}
\hline Model & $\mathbf{R}$ & $\begin{array}{c}\mathbf{R} \\
\text { Square }\end{array}$ & $\begin{array}{c}\text { Adjusted } \\
\text { R Square }\end{array}$ & $\begin{array}{c}\text { Std. Error } \\
\text { of the } \\
\text { Estimate }\end{array}$ & $\begin{array}{c}\text { Durbin- } \\
\text { Watson }\end{array}$ \\
\hline 1 & $\begin{array}{r}.706 \\
\mathrm{a}\end{array}$ & $\mathbf{. 4 9 8}$ & .469 & 7.873 & 1.813 \\
\hline
\end{tabular}

a. Predictors: (Constant), Kemampuan Kerja,

Lingkungan Kerja

b. Dependent Variable: Y

Sumber: Hasil Pengolahan Data 2015

Berikut adalah hasil perhitungan koefisien determinasi $X_{1}, X_{2}$, dan Y:

$\mathrm{KD} X_{1}$ dan $X_{2}$ terhadap $\mathrm{Y}=r^{2} \times 100 \%=$ $(0,706)^{2} \times 100=49,84 \%$

Koefisien determinasi untuk lingkungan kerja $\left(X_{1}\right)$ dan kemampuan kerja $\left(X_{2}\right)$ terhadap kinerja karyawan (Y) adalah 49,84\%. Dengan kata lain kinerja karyawan dipengaruhi 49,84\% oleh lingkungan kerja dan kemampuan kerja, sedangkan 50,16\% dipengaruhi oleh faktorfaktor lainnya yang tidak diteliti dalam penelitian ini.

Adapun besarnya pengaruh secara parsial antara kemampuan kerja terhadap kinerja karyawan dapat dilihat pada Tabel masingmasing variabel dapat dilihat pada Tabel Standardized Coefficients (Beta) adalah lingkungan kerja terhadap kinerja karyawan mempunyai pengaruh sebesar $7,8 \%$ artinya kinerja karyawan dipengaruhi lingkungan kerja sebesar 7,8\% dan sisanya $92,2 \%$ dipengaruhi oleh faktor lainnya yang tidak diteliti dalam penelitian ini. Kemampuan kerja terhadap kinerja karyawan mempunyai pengaruh sebesar $66,5 \%$ yang artinya kinerja karyawan dipengaruhi kemampuan kerja sebesar $66,5 \%$ dan sisanya $33,5 \%$ dipengaruhi oleh faktor lain. Berdasarkan paparan di atas berikut pengaruh lingkungan kerja dan kemampuan kerja terhadap kinerja karyawan PT. Ronadamar Sejahtera pada Gambar 2 berikut ini:

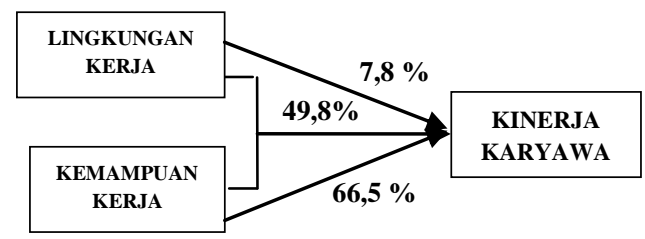

Sumber: Hasil Pengolahan Data 2015
Uji Hipotesis

TABEL5

NILAI SIGNIFIKANSI UJI F ANOVA

\begin{tabular}{|cc|c|c|c|c|c|}
\hline \multirow{2}{*}{ Model } & $\begin{array}{c}\text { Sum of } \\
\text { Squares }\end{array}$ & df & $\begin{array}{c}\text { Mean } \\
\text { Square }\end{array}$ & F & Sig. \\
\hline & Regression & 2095.023 & 2 & 1047.511 & $\mathbf{1 6 . 8 9 8}$ & $\begin{array}{c}.000 \\
\mathrm{~b}\end{array}$ \\
\hline & & & & & \\
\hline & Residual & 2107.686 & 34 & 61.991 & & \\
& Total & 4202.709 & 36 & & & \\
\hline
\end{tabular}

a. Dependent Variable: Kinerja

b. Predictors: (Constant), Kemampuan Kerja,

Lingkungan Kerja

Sumber: Hasil Pengolahan Data 2015

Tabel menunjukan pengujian untuk uji $\mathrm{F}$ yang diambil dari Anova dengan tingkat probabilitas $(\mathrm{Sig})=0,000$, maka taraf signifikan 0,05 yaitu $0,000 \leq 0,05$. maka keputusan adalah $\mathrm{H}_{\mathrm{o}}$ ditolak. Artinya terdapat pengaruh yang positif antara pengaruh lingkungan kerja dan kemampuan kerja terhadap kinerja karyawan PT. Ronadamar Sejahtera.

Peneliti juga melakukan pengujian pengaruh variabel bebas secara bersama-sama terhadap variabel terikat dengan menggunakan uji $\mathrm{F}$ yaitu $F_{\text {hitung }}>F_{\text {tabel }}$. Maka $F_{\text {tabel }}$ dengan 37 responden yaitu pada $\mathrm{a}=0,05$ adalah 3,276 . Sehingga didapat $16,898>3,276$, maka $\mathrm{H}_{\mathrm{o}}$ ditolak. Kesimpulannya sama dengan pengujian yang dilakukan dengan menggunakan nilai probabilitas. Dengan demikian dapat disimpulkan bahwa hipotesis dalam penelitian ini yaitu $\mathrm{H}_{\mathrm{o}}$ ditolak dan $\mathrm{H}_{\mathrm{a}}$ diterima, Dengan demikian dapat disimpulkan bahwa hipotesis dalam penelitian ini yaitu $\mathrm{H}_{\mathrm{o}}$ ditolak dan $\mathrm{H}_{\mathrm{a}}$ diterima, sehingga:

1. Terdapat pengaruh positif dari lingkungan kerja dan kemampuan kerja terhadap kinerja karyawan PT. Ronadamar Sejahtera Bandung

2. Terdapat pengaruh positif dari lingkungan kerja terhadap kinerja karyawan PT. Ronadamar Sejahtera Bandung

3. Terdapat pengaruh positif dari kemampuan kerja terhadap kinerja karyawan PT. Ronadamar Sejahtera Bandung

\section{KESIMPULAN DAN REKOMENDASI}

\section{KESIMPULAN}

1. Hasil penelitian menyatakan bahwa, lingkungan kerja pada PT. Ronadamar Sejahtera berada pada kategori baik. Hal ini menunjukkan bahwa lingkungan kerja PT. Ronadamar Sejahtera sudah baik. Dimensi yang memiliki penilaian paling tinggi yaitu lingkungan kerja fisik dengan perolehan skor 1872 atau sebesar $77,8 \%$ sedangkan 
dimensi lingkungan kerja non fisik yang memiliki penilaian paling rendah yaitu dengan perolehan skor 1302 atau sebesar $78,2 \%$.

2. Hasil penelitian menyatakan bahwa, kemampuan kerja karyawan pada PT. Ronadamar Sejahtera berada pada ketegori baik. Hal ini menujukkan bahwa kemampuan kerja karyawan PT. Ronadamar Sejahtera sudah baik. Dimensi yang memiliki penilaian paling tinggi yaitu kemampuan fisik dengan perolehan skor 585 atau sebesar 79,1\% sedangkan dimensi yang memiliki penilaian paling rendah yaitu kemampuan kogniitif dengan perolehan skor 579 atau sebesar $78,2 \%$.

3. Hasil penelitian menyatakan bahwa, kinerja karyawan PT. Ronadamar Sejahtera berada pada ketegori tinggi. Hal ini menunjukkan bahwa kinerja karyawan PT. Ronadamar Sejahtera sudah baik. Dimensi yang memiliki penilaian paling tinggi yaitu kompetensi (competencies) dengan perolehan skor 741 atau sebesar $80,1 \%$ sedangkan dimensi yang memiliki penilaian paling rendah yaitu kuantitas pekerjaan yang dilakukan (Quantity of Work Performed) dengan perolehan skor 439 atau sebesar $79,1 \%$.

4. Lingkungan kerja dan kemampuan kerja mempunyai pengaruh yang positif terhadap kinerja karyawan dengan pengaruh langsung sebesar 49,8\%. Hal ini menunjukkan bahwa semakin baik pelaksanaan lingkungan kerja dan kemampuan kerja karyawan, maka akan semakin baik pula kinerja karyawan tersebut.

5. Hasil penelitian menyatakan bahwa lingkungan kerja mempunyai pengaruh positif terhadap kinerja karyawan dengan pengaruh secara langsung sebesar 78\%. Hal ini menujukan bahwa semakin baik pelaksanaan, maka semakin baik pula kinerja karyawan tersebut.

6. Hasil penelitian menyatakan bahwa kemampuan kerja mempunyai pengaruh positif terhadap kinerja karyawan dengan pengaruh langsung $66,5 \%$. Hal ini menujukan bahwa semakin baik kemampuan kerja yang dimiliki karyawan, maka semakin baik pula kinerja karyawan tersebut.

\section{REKOMENDASI}

1. Lingkungan kerja di perusahaan sangatlah penting untuk menunjang kinerja setiap karyawan dalam penyelesaian pekerjaannya. Lingkungan kerja di PT. Ronadamar Sejahtera dapat ditingkatkan pada aspek lingkungan kerja non fisik. Dimensi lingkungan kerja fisik ini dapat ditingkatkan dengan memperbaiki komunikasi antara atasan dan bawahan, atasan harus lebih mengarahkan pekerjaan yang harus dilaksanakan oleh karyawannya, atasan lebih mengawasi karyawannya dalam menyelesaikan pekerjaannya, apabila hal ini diterapkan secara terus-menerus maka karyawan dapat membantu perusahaan untuk mencapai tujuannya.

2. Kemampuan kerja harus dimiliki setiap karyawan di setiap perusahaan, karena dengan memiliki kemampuan kerja yang baik karyawan dapat bekerja sesuai dengan aturan yang dibuat perusahaan. Kemampuan kerja PT. Ronadamar Sejahtera dapat ditingkatkan pada aspek kemampuan kognitif (cognitive abilities) dengan cara perusahaan harus memberikan contoh bagaimana berbagi informasi lalu menyampaikannya dengan baik, agar dapat mengidentifikasi masalah dan dapat menyelesaikan masalah pekerjaan tersebut dengan baik. Sehingga permasalahan yang ada dalam pekerjaan dapat terselesaikan dengan cepat.

3. Kinerja karyawan PT. Ronadamar Sejahtera dapat ditingkatkan pada aspek kuantitas pekerjaan yang dilakukan (quantity of work) dengan cara memberikan pengarahan kepada karyawan mengenai target pekerjaan yang harus dicapai, untuk meningkatkan hasil kerja sesuai dengan standar yang telah ditentukan oleh perusahaan, dan diharapkan dapat menggunakan waktu dengan sebaikbaiknya tidak melebihi waktu yang telah ditentukan.

4. Hasil penelitian menyatakan bahwa lingkungan kerja dan kemampuan kerja berpengaruh secara positif terhadap kinerja karyawan, maka dengan demikian penulis merekomendasikan agar perusahaan tetap menjaga, mempertahankan, dan meningkatkan kinerja karyawan melalui pelaksanaan lingkungan kerja dan kemampuan kerja untuk mencapai tujuan perusahaan.

5. Hasil penelitian ini menyatakan bahwa lingkungan kerja berpengaruh positif terhadap kinerja karyawan, maka dengan demikian penulis merekomendasikan agar perusahaan terus meningkatkan pelaksanaan lingkungan kerja dengan terus meningkatkan fasilitas yang mendukung di tempat kerja maupun meningkatkan hubungan dengan atasan maupun sesama karyawan yang ada di lingkungan perusahaan. sehingga proses pelaksanaan lingkungan kerja dapat berjalan dengan baik, dan karyawan memiliki kinerja yang baik pula dalam melaksanakan 
pekerjaan sesuai dengan standar yang ditentukan di perusahaan.

6. Hasil penelitian menyatakan bahwa kemampuan kerja berpengaruh positif terhadap kinerja karyawan, maka dengan demikian penulis merekomendasikan agar perusahaan terus meningkatkan kemampuan kerja yang dimiliki oleh karyawan dengan diadakannya program untuk menambah wawasan bagi karyawan, keterampilan saat bekerja, sehingga karyawan memiliki semangat untuk bekerja dengan bersungguhsungguh dan memiliki kemampuan kerja yang baik dalam bekerja.

7. Penelitian ini diharapkan dapat dijadikan sebagai dasar dalam melakukan penelitian mengenai lingkungan kerja dan kemampuan kerja dengan indikator serta objek yang berbeda.

\section{DAFTAR PUSTAKA}

Badeni. 2013. Kepemimpinan dan Perilaku Organisasi. Bandung: CV. Alfabeta

Chatab, Nevizond.2009. Mengawal Pilihan Rancangan Organisasi, Organization Theory, Design \& Structured Network. Bandung: CV. Alfabeta.

Dessler, Gary. 2010. Human Resource Management Tenth Edition, Alih Bahasa: Pramitha Rahayu. Jakarta: PT. Indeks

Gomez-Mejia, Luis R and David B. Balkin and Robert L. Cardy. 2012. Managing Human Resources. United States: Pearson Education, Inc., publishing as Prentice Hall.

Hasibuan, Malayu. 2014. Manajemen, Dasar Pengertian dan Masalah. Jakarta: Bumi Aksara

Mangkunegara, Anwar Prabu. 2008. Perilaku dan Budaya Organisasi. Bandung: PT. Refika Aditama

2011

Manajemen Sumber Daya Manusia Perusahaan. Bandung: PT. Remaja Rosdakarya

2012. Evaluasi Kinerja Sumber daya Manusia. Bandung: PT. Refika Aditama

Rivai, Veithzal dan Ella Sagala. 2010. Manajemen Sumber Daya Manusia untuk Perusahaan: Dari Teori ke Praktik. Jakarta: PT RajaGrafindo Persada

Sedarmayanti. 2012. Manajemen dan Komponen Terkait Lainnya. Bandung: PT. Refika Aditama

\footnotetext{
2014. Manajemen Sumber Daya Manusia, Reformasi Birokrasi dan Manajemen Pegawai Negeri Sipil. Bandung: PT. Refika Aditama
}

2009. Sumber Daya Manusia dan Produktivitas Kerja. Bandung: Mandar Maju

$$
\text { 2011. Tata Kerja dan }
$$

Produktivitas Kerja. Bandung: Mandar Maju

Sugiono. 2012. Metode Penelitian Kuantitatif Kualitatif dan $R \& D$. Bandung: $\mathrm{CV}$. Alfabeta.

. 2013. Metode Penelitian Bisnis. Bandung: CV. Alfabeta.

Sunyoto, Danang. 2012. Teori, Kuesioner, dan Analisis Data Sumber Daya Manusia. Yogyakarta: CAPS

Wibowo. 2013. Perilaku dalam Organisasi.. Jakarta: PT. Raja Grafindo Persada 2012. Manajemen Kinerja. Jakarta: PT.

Raja Grafindo Persada

\section{Jurnal}

Asigele Oswald. 2012. The Effect of Working Environment on Workers Performance: The Case of Reproductive and Child Health Care Providers in Tarime District.

Diah, Ari, and Andi. 2013. Pengaruh Kemampuan Kerja dan Motivasi Kerja Terhadap Kinerja Karyawan. Diponegoro journal of social and politic

Dina Khairani Sofyan. 2013. Pengaruh Lingkungan Kerja Terhadap Kinerja Kerja Pegawai BAPPEDA. Malikussaleh Industrial Engineering Journal Vol.2 No.1

Nirza, Andrian. 2012. Pengaruh Lingkungan Kerja dan Karakteristik Individu Terhadap Kepuasan Kerja Karyawan Hotel Melati di Kecamatan Banjarmasin Tengah. Volume 13 Nomor 1

Risqon, Didik Purwadi. 2012. Pengaruh Kepemimpinan, Kompetensi, dan Kemampuan Kerja Terhadap Kinerja Karyawan. DAYA SAING Jurnal Ekonomi Manajemen Sumber Daya. Vol. 13, No. 1.

Sukamto, Masjaya, Riady. 2013. Pengaruh Lingkungan Kerja Fisik dan Non Fisik Terhadap Kinerja Pegawai Pada Badan Ketahanan Pangan dan Pelaksana Penyuluhan Daerah Kota Samarinda. eJournal Administrative Reform, 2013, 1 (2): 431-443

Gina Aprilita Susanty. 2011. Pengaruh Kemampuan Kerja dan Kualitas Layanan Pegawai Terhadap Kepuasan Nasabah BNI Cabang UPI. Repository.upi.edu, Bandung 